Tropical Journal of Pharmaceutical Research March 2020; 19 (3): 645-650

ISSN: $1596-5996$ (print); 1596-9827 (electronic)

(C) Pharmacotherapy Group, Faculty of Pharmacy, University of Benin, Benin City, 300001 Nigeria.

Available online at http://www.tjpr.org

Original Research Article

http://dx.doi.org/10.4314/tjpr.v19i3.27

\title{
Chemical composition and anti-arthritic activity of the essential oil from Litsea cubeba against Type II collagen rheumatoid arthritis in rat collagen
}

\author{
Jiancun Zhao ${ }^{1 *}$, Qianqian Wang ${ }^{2}$, Jie $\mathbf{M a}^{1}$ \\ ${ }^{1}$ Department of Orthopaedics, ${ }^{2}$ Department of Rheumatology and Immunology, Xintai People's Hospital, 1329 Xinfu Road, \\ Xintai City, Shandong Province 271200, PR China
}

*For correspondence: Email: zhaojcxthp@163.com; Tel: +18753867231

Sent for review: 6 February 2019

Revised accepted: 22 February 2020

\begin{abstract}
Purpose: To study the curative effect of the volatile oil from Litsea cubeba (EOL) on type I/ collagen (CII) induced arthritic (CIA) rat.

Methods: The chemical constituents of EOL were analyzed by gas chromatography-mass spectrometry (GC-MS). The analgesic effect of the oil was assessed by acetic acid-stimulated torsion and hot plate methods, while antiinflammatory potential was further assessed by in an ear oedema model induced by dimethylbenzene in mice. The anti-rheumatoid arthritis (RA) activity of EOL in mice was evaluated in terms of paw volume, arthritis index, thymus and spleen index, and serum inflammatory factor levels. Results: GC-MS showed that $\alpha$-citral (26.42\%), $\beta$-citral (21.94\%), and limonene (12.79\%) were the main components of EOL. Different doses of EOL (50, 100, $200 \mathrm{mg} / \mathrm{kg})$ exerted varying inhibitory effects on torsion in mice induced by acetic acid $(p<0.01)$ but had no significant effect on thermal stimulation-induced pain. EOL reduced ear oedema in mice $(p<0.01)$. In addition, EOL (50, 100, 200 $\mathrm{mg} / \mathrm{kg}$ ) reduced the mouse paw volume, arthritis index, and thymus and spleen index $(p<0.01)$. Furthermore, EOL reduced proinflammatory cytokines in serum but increased antiinflammatory cytokines $(p<0.01)$.

Conclusion: EOL ameliorates symptoms of inflammation in CIA rats by inhibiting inflammatory
\end{abstract} reactions, suggesting it could be further developed as an anti-arthritic drug.

Keywords: Litsea cubeba, Essential oil, Rrheumatoid arthritis, Pro-inflammatory cytokines

\begin{abstract}
This is an Open Access article that uses a fund-ing model which does not charge readers or their institutions for access and distributed under the terms of the Creative Commons Attribution License (http://creativecommons.org/licenses/by/4.0) and the Budapest Open Access Initiative (http://www.budapestopenaccessinitiative.org/read), which permit unrestricted use, distribution, and reproduction in any medium, provided the original work is properly credited.

Tropical Journal of Pharmaceutical Research is indexed by Science Citation Index (SciSearch), Scopus, International Pharmaceutical Abstract, Chemical Abstracts, Embase, Index Copernicus, EBSCO, African Index Medicus, JournalSeek, Journal Citation Reports/Science Edition, Directory of Open Access Journals (DOAJ), African Journal Online, Bioline International, Open-J-Gate and Pharmacy Abstracts
\end{abstract}

\section{INTRODUCTION}

Previous studies have demonstrated that rheumatoid arthritis (RA) is an intractable inflammatory polyarthritis that can result in serious damage to joints, commonly resulting in gradual cartilage and synovial bone destruction, loss of joint function, and disability [1-3]. RA can also lead to other systemic organ disorders by affecting the structures of the heart, lungs, and kidneys [4]. The most commonly prescribed drugs for treatment of RA are disease-modifying anti-rheumatic drugs (DMARDs), antiinflammatory agents and biological agents; however, these drugs could result in some bothersome side effects for long-time use [5]. In 
recent years, essential oils (EOs) have attracted more and more attention, previous reports found that EOs have a lot of biological effects such as antiinflammation, anti-bacteria, antitumor, and antioxidation [6,7]. Litsea cubeba (belonging to the Lauraceae family) is a well-known herbal medicine in Chinese folk medicine for treating inflammatory and rheumatic diseases $[8,9]$. Furthermore, extracts/constituents derived from L. cubeba may have a significant effect on RA [10]. However, there is no report regarding the anti-RA effects of the essential oil from $L$. cubeba (EOL). This paper was designed to study the curative effects of EOL on RA with collageninduced arthritis $(\mathrm{CIA})$ rats to provide important experimental evidence to guide its future clinical uses.

\section{EXPERIMENTAL}

\section{Animals}

Institute of Cancer Research (ICR) mice and Sprague Dawley (SD) rats were acquired from the Animal Center of Shanghai (Shanghai, China). The protocols for animal studies were designed obeyed the international animal use guidelines [11] and authorized by the ethics committee for animal experiment of Xintai People's Hospital (approval ref no. 20170604\#).

\section{Chemicals and reagents}

Type II collagen (CII), indomethacin, methotrexate (MTX), and complete Freund's adjuvant (CFA) were supplied by Sigma (USA); enzyme-linked immunosorbent assay (ELISA) kits for interleukin (IL)-1 $\beta,-6,-8,-10$, and $-17 \mathrm{~A}$, and tumor necrosis factor (TNF) $-\alpha$ were acquired from the R\&D System Co. (USA); dimethylbenzene and acetic acid was supplied by the Sinoreagent Co. (Shanghai, China).

\section{L. cubeba plant material and preparation of EOL}

Fresh fruits of Litsea cubeba were collected in June 2017 from Guiyang, Guizhou province, China. EOL was prepared using a hydrodistillation method reported by Zhou and Mo [12]. The fresh $L$. cubeba fruits were boiled in 5 volumes of water for $120 \mathrm{~min}$. Then, the EOL was extracted using the $n$-hexane and dried with the sodium sulfate anhydrous (EOL yield was approximately $4.3 \% \mathrm{v} / \mathrm{w}$ ).

\section{GC-MS analysis}

The constituent analysis of EOL was done on a 6890 gas chromatograph and 5973 mass spectrometer (Agilent Tech., Santa Clara, CA, USA). EOL was analyzed with HP-5MS $5 \%$ Pheneyl Methyl Siloxane capillary column (30 m $\times 0.25 \mathrm{~mm} \times 0.25 \mu \mathrm{m})$. The started temperature for column was $50{ }^{\circ} \mathrm{C}$, and subsequently increased to $180{ }^{\circ} \mathrm{C}$ at $2{ }^{\circ} \mathrm{C}$ per min. The carrier gas was helium $(1.0 \mathrm{~mL} / \mathrm{min})$. The split rate was $40: 1$, and the inlet volume was set as $1.0 \mu \mathrm{L}$. The ion energy was set as $70 \mathrm{eV}$, and the scanned mass range was $10-550$ a.m.u. with acquisition mode of the full-scan. Constituents were authenticated by comparing the National Institute of Standards and Technology Mass Spectral Search Program (NIST, USA), and the relative contents of identified compounds in EOL were calculated using area normalization method.

\section{Acetic acid-stimulated torsion method}

The analgesic effect of EOL was evaluated following acetic acid stimulated torsion study in mice according to the reported method with minor modification [13]. The experiment is consisted of five groups (10 mice in each group): control, positive (indomethacin, $10 \mathrm{mg} / \mathrm{kg}$ ), and EOL $(50 \mathrm{mg} / \mathrm{kg}, 100 \mathrm{mg} / \mathrm{kg}$ and $200 \mathrm{mg} / \mathrm{kg}$ ). Indomethacin and EOL were treated orally, and control mice were treated orally with an equal volume of CMC-Na. At 30 min after drug intervening, mice were intraperitoneally (i.p.) administered with $0.2 \mathrm{~mL} 1.0 \%$ acetic acid, and the writhing frequency was recorded for $15 \mathrm{~min}$.

\section{Hot plate method}

Hot plate testing was carried out following a previous method with minor modification [14]. The experiment design consisted of five groups (10 mice in each group): control, positive (indomethacin, $10 \mathrm{mg} / \mathrm{kg}$ ), and three doses of EOL $(50,100$ and $200 \mathrm{mg} / \mathrm{kg})$. Indomethacin and EOL were given orally, and control mice were orally given an equal volume of $0.5 \%$ CMC-Na. At $30 \mathrm{~min}$ after drug administration, mice were placed on an intelligent hot plate instrument with the temperature set at $55 \pm 0.5^{\circ} \mathrm{C}$, and the time to initiate paw-licking behavior was recorded as an indicator of pain response.

\section{Induction of edema by dimethylbenzene}

The anti-inflammatory property of EOL was studied in an ear edema model [13]. The experiment is consisted of five groups (10 mice in each group): control, positive (indomethacin, $10 \mathrm{mg} / \mathrm{kg}$ ) and EOL (50 mg/kg, $100 \mathrm{mg} / \mathrm{kg}$ and $200 \mathrm{mg} / \mathrm{kg}$ ). Indomethacin and EOL were given orally, and control mice were given the same amount of $0.5 \%$ CMC-Na. At $30 \mathrm{~min}$ after drug administration, dimethylbenzene $(50 \mu \mathrm{L})$ was 
evenly applied to the front and back of the right ears of all mice, excluding the control group. The dimethylbenzene was allowed to sit for $1 \mathrm{~h}$ before mice were sacrificed under anesthesia (pentobarbital sodium injection, $40 \mathrm{mg} / \mathrm{kg}$ ), and the ears of each mouse were cut off and weighed with an electronic analytical balance.

\section{Establishment of collagen-induced arthritis (CIA) rat}

The Cll-induced RA (CIA) rat model was prepared following the previous report [15]. Briefly, the experiment was consisted of six groups (10 rats in each group): normal, control, positive (MTX), and three EOL doses (50, 100, $200 \mathrm{mg} / \mathrm{kg}$ ). Cll was dissolved using acetic acid $(0.1 \mathrm{mM})$ solution to give a final concentration of CIl of $4 \mathrm{mg} / \mathrm{mL}$. The CIl solution was emulsified with the same volume of CFA to prepare the immunogen. For the initial immunization, all rats, excluding the normal group, were injected with $0.1 \mathrm{~mL}$ at the left posterior, toe skin, neck, back, and tail root $(0.5 \mathrm{~mL}$ in total). At 7 days after the first immunization, the same dose of immunogen was used to strengthen the immunization at the same place. From days 1 to 24 following the initial Cll immunization, and MTX $(1.0 \mathrm{mg} / \mathrm{kg}$, thrice per week) used as the positive control, and the three EOL groups were treated with EOL (50, $100,200 \mathrm{mg} / \mathrm{kg}$ ), The normal and control groups were given with $0.5 \%$ CMC-Na. During the experiment, paw volume was measured every 3 days using an YLS-7C paw volume meter (TECHMAN SOFT, Chengdu, China), and the arthritis score was calculated every 3 days after the first injection using the a five-point scale: $(0)$ no redness or swelling, (1) swelling and erythema can be seen in 1 joint, (2) swelling and erythema can be seen in 2 joints, (3) swelling and erythema can be seen in 3 joints, and 4) maximal erythema and swelling can be seen in 3 joints affected.

\section{Spleen and thymus indices}

Under anesthesia (pentobarbital sodium injection, $40 \mathrm{mg} / \mathrm{kg}$ ) and rats' blood was collected using orbital sampling. Then, the thymus tissues and spleen tissues were collected and weighed. The thymus indices and spleen indices are calculated as the ratio of the thymus tissues or spleen tissues wet weight divided by the rats' weight $(\mathrm{mg} / \mathrm{g})$.

\section{ELISA}

Rat blood was centrifuged $(1,800 \times g, 15 \mathrm{~min})$ at $4{ }^{\circ} \mathrm{C}$ to separate the serum samples, and kept under $-80^{\circ} \mathrm{C}$ before biochemical analysis. Then, the levels of TNF- $\alpha, \mathrm{IL}-1 \beta,-6,-8,-10$, and $-17 \mathrm{~A}$ were evaluated by ELISA kits following the manufacturer's instruction.

\section{Statistical analysis}

Data are presented as mean \pm standard deviation (SD), and differences between groups were determined using one-way analysis of variance with the aid of SPSS 15.0 (USA). $P<$ 0.05 was taken as significant.

\section{RESULTS}

\section{Identified constituents from EOL}

The GC/MS results showed the main chemical compositions from EOL were $\alpha$-pinene, $\beta$ myrcene, eucalyptol, limonene, linalool, $\beta$-citral, geraniol, $\alpha$-citral, $\gamma$-elemene, Cis-nerolidol, caryophyllene oxide, and dodecanoic acid ethyl ester (Table 1). In addition, the predominant chemical constituents were $\alpha$-citral $(26.42 \%)$, $\beta$ citral (21.94 \%), and limonene (12.79\%), accounting for $>50 \%$ of the identified constituents.

Table 1: Chemical composition of the essential oil from Litsea cubeba

\begin{tabular}{lcr}
\hline Compound & $\begin{array}{c}\text { Molecular } \\
\text { formula }\end{array}$ & $\begin{array}{c}\text { Content } \\
\text { (\%) }\end{array}$ \\
\hline$\alpha$-Pinene & $\mathrm{C}_{10} \mathrm{H}_{16}$ & 3.67 \\
$\beta$-Myrcene & $\mathrm{C}_{30} \mathrm{H}_{16}$ & 5.28 \\
Eucalyptol & $\mathrm{C}_{30} \mathrm{H}_{18} \mathrm{O}$ & 6.79 \\
Limonene & $\mathrm{C}_{10} \mathrm{H}_{16}$ & 12.79 \\
Linalool & $\mathrm{C}_{10} \mathrm{H}_{18} \mathrm{O}$ & 3.92 \\
$\beta$-citral & $\mathrm{C}_{30} \mathrm{H}_{16} \mathrm{O}$ & 21.94 \\
Geraniol & $\mathrm{C}_{10} \mathrm{H}_{18} \mathrm{O}$ & 4.39 \\
$\alpha$-Citral & $\mathrm{C}_{30} \mathrm{H}_{16} \mathrm{O}$ & 26.42 \\
-Elemene & $\mathrm{C}_{15} \mathrm{H}_{24}$ & 1.32 \\
Cis-Nerolidol & $\mathrm{C}_{15} \mathrm{H}_{26} \mathrm{O}$ & 1.04 \\
Caryophyllene & $\mathrm{C}_{15} \mathrm{H}_{24} \mathrm{O}$ & 1.27 \\
oxide & & \\
Dodecanoic acid & $\mathrm{C}_{14} \mathrm{H}_{28} \mathrm{O}$ & 1.74 \\
ethyl ester & & \\
\hline
\end{tabular}

EOL inhibits inflammatory reactions and nociception in animals

As can be observed from Figure $1 \mathrm{~A}$, the number of writhing reactions in mice in the indomethacin and $\operatorname{EOL}(50,100$, and $200 \mathrm{mg} / \mathrm{kg}$ ) rats reduced obviously ( $p<0.01$, vs. control mice). The analgesic effects of EOL were dose dependent (Figure $1 \mathrm{~B}$ ). There was no difference in pain threshold in EOL treatment groups $(p>0.05)$, but the standard drug (morphine) had a strong analgesic effect on hot plate-induced pain ( $p<$ 0.01). These results suggested the antinociceptive activity of the EOL might be closely 
related to the peripheral analgesic route rather than the central analgesic route.

The anti-inflammatory potential of EOL was studied by the suppression of ear edema induced by dimethylbenzene (Figure $1 \mathrm{C}$ ). Similar to the anti-inflammatory effect of indomethacin, EOL significantly decreased ear edema at $50 \mathrm{mg} / \mathrm{kg}$, $100 \mathrm{mg} / \mathrm{kg}$, and $200 \mathrm{mg} / \mathrm{kg}$ ( $p<0.01$, vs. control mice). The dimethylbenzene-induced ear edema results suggest that EOL possesses antiinflammatory properties.

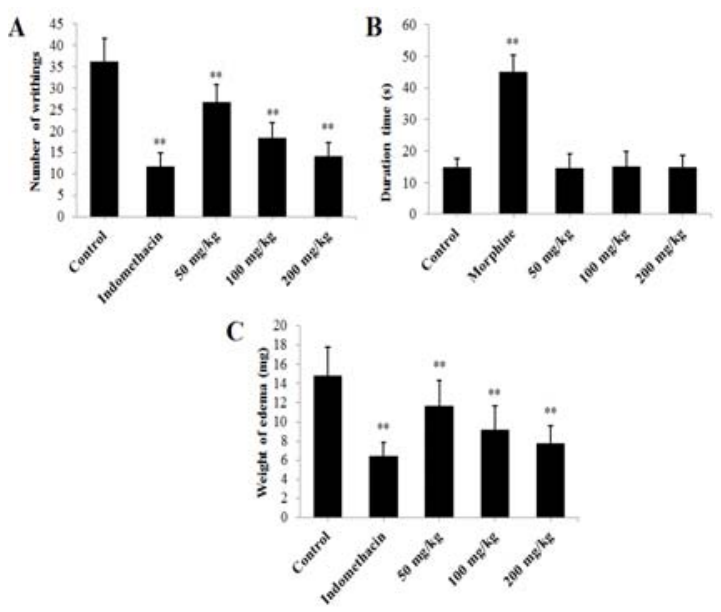

Figure 1: Effect of EOL on acetic acid-induced writhing responses $(A)$, thermal-induced nociception $(B)$ and ear edema induced by dimethylbenzene $(C)$ in mice. Data are expressed as the mean \pm SD $(n=10)$; ${ }^{* *} p<0.01$ vs. control mice

\section{EOL reduced paw swelling and arthritis index}

To study the potentials of EOL on RA, the paw swelling and arthritis scores of rats were determined (Figure $2 \mathrm{~A}$ and $\mathrm{B}$ ). Control CIA rats showed significant paw swelling and increased arthritis scores $(\mathrm{P}<0.01$, vs. normal control rats). After MTX treatment, the paw swelling and arthritis scores were significantly reduced $(p<$ 0.01 , vs. ClA control group), and the paw swelling and arthritis scores of EOL treated CIA rats $(50,100$ and $200 \mathrm{mg} / \mathrm{kg}$ ) were reduced $(p<$ 0.01 , vs. control group).

\section{EOL reduced indices of spleen \& thymus}

Effects of EOL on indices of spleen and thymus are shown in Figure $3 \mathrm{~A}$ and $\mathrm{B}$. Both indexes in control CIA rats were increased $(P<0.01$, vs. normal control rats). However, after positive drug treatment (MTX), the indexes in CIA rats reduced $(P<0.01)$. The thymus and spleen indexes of EOL-treated rats decreased $(P<0.01$, vs. control rats), indicating that EOL can regulate immune functions in CIA rats.

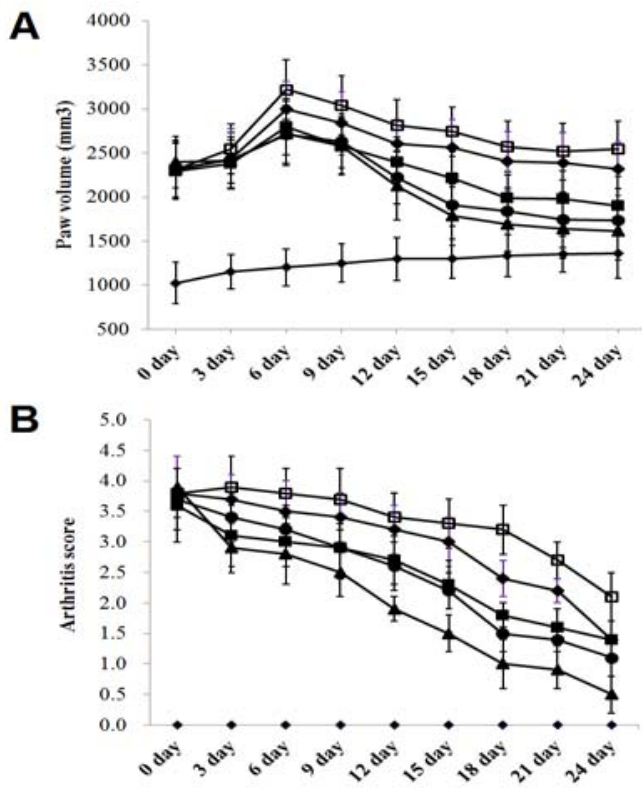

Figure 2: Effects of EOL on paw volume (A) and arthritis scores $(B)$ of $\mathrm{CIA}$ rats. Data are expressed as mean \pm SD $(n=10) .{ }^{* *} P<0.01$ vs. control rats. CIA: type II collagen-induced arthritis; MTX: methotrexate.

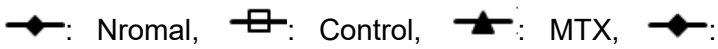
$50 \mathrm{mg} / \mathrm{kg}, \multimap-100 \mathrm{mg} / \mathrm{kg}, \multimap: 200 \mathrm{mg} / \mathrm{kg}$

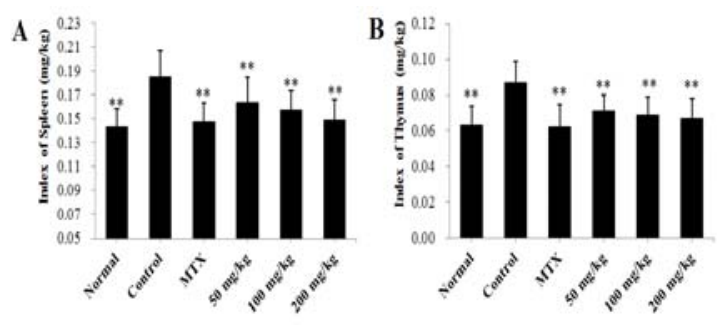

Figure 3: Effects of EOL on index of the $(A)$ spleen and $(B)$ thymus in CIA rats. Data are expressed as the mean $\pm \mathrm{SD}(\mathrm{n}=10) .{ }^{* *} P<0.01$ vs. control group. CIA: type II collagen-induced arthritis; MTX: methotrexate

\section{EOL reduces inflammatory cytokines}

The levels of inflammatory cytokines (TNF- $\alpha$, IL$1 \beta,-6,-8,-10$, and $-17 A$ ) are shown in Figure 4. Control CIA rats had higher levels of TNF- $\alpha$, IL$1 \beta,-6,-8$, and $-17 \mathrm{~A}$, but lower IL-10 $(p<0.01$, vs. normal control rats). After MTX treatment (3 $\mathrm{mg} / \mathrm{kg}$ ), the TNF- $\alpha$, IL-1 $1,-6,-8$, and $-17 \mathrm{~A}$ in serum were significantly reduced $(P<0.01$, vs. CIA control rats), whereas IL-10 was significantly higher $(P<0.01)$. Similar to MTX, EOL treatment $(50,100$, and $200 \mathrm{mg} / \mathrm{kg}$ ) also significantly reduced the levels of TNF- $\alpha, \mathrm{IL}-1 \beta,-6,-8$, and $17 \mathrm{~A}$ and increased IL-10 in serum $(p<0.01$, vs. CIA control rats).

Trop J Pharm Res, March 2020; 19(3): 648 


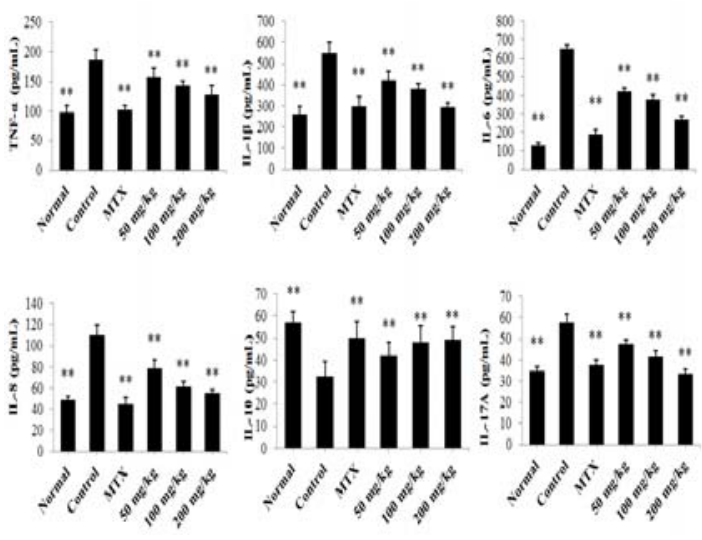

Figure 4: Effect of EOL on the serum levels of TNF- $\alpha$, IL-1 $\beta$, IL-6, IL-8, IL-10 and IL-17A in CIA rats. Data are expressed as mean \pm SD $(n=10)$, ${ }^{* *} P<0.01$, vs. control group. CIA: type II collagen-induced arthritis; MTX: methotrexate; IL: interleukin; TNF- $\alpha$ : tumor necrosis factor- $\alpha$

\section{DISCUSSION}

It's known that RA is a complex chronic autoimmune disease lacking a clear pathogenesis and curative treatment. A growing body of evidence suggests that traditional drugs have good anti-RA effects, such as improving inflammation, reducing cytokine levels, and inducing apoptosis of synovial fibroblasts [16]. $L$. cubeba is an effective herbal folk medicine used in China to treat various inflammatory diseases and RA. Several traditional medicinal uses have been confirmed by modern pharmacological investigations. Through literature review, we found that the EO content in this plant is very high, and increasing reports indicate that natural EOs have anti-inflammatory potential $[5,16,17]$. Thus, EOL might be containing the main active components of $L$. cubeba responsible for antiinflammatory and analgesic effects. The primary constituents of EOL were determined as $\alpha$-citral (26.42 \%), $\beta$-citral (21.94\%), and limonene $(12.79 \%)$, which were also reported as antiinflammatory agents in a previous study [18].

This study revealed that EOL has an analgesic activity on acetic acid-induced torsion, but there was no obvious analgesic effect on pain due to heat stimulation. In addition, ear edema in mice induced dimethylbenzene was measured. The experimental results showed that EOL reduced the ear swelling rate in mice. These results suggest that EOL has anti-inflammatory and analgesic effects related to the peripheral analgesic route instead of central analgesic route, and could be used as a natural antiinflammatory and analgesic drug. The CIA rat model is one of the most commonly studied animal models for RA research. Its induced immune response, pathological features, and inflammatory manifestations are similar to those observed in human RA. Thus, it is widely used to study disease pathogenesis, screen potential therapeutic drugs, and study the effects of antiRA drugs $[19,20]$.

After EOL treatment, paw volume and arthritis score of CIA rats were significantly reduced, as were the thymus and spleen indexes. These results demonstrate that EOL could reduce inflammation and affect immune function in CIA rats. Experimental studies have shown that mechanism for EOL treating $R A$ is related to regulation of inflammatory cytokines.

It is known that inflammatory cytokines show crucial effects in occurrence and development of RA and are therefore considered as potential therapeutic targets. Cytokines such as TNF-a, ILs have been reported to stimulate degradation of cartilage matrix and contribute to the RA development, whereas IL-10 is a negative regulating factor of inflammatory reactions. The present findings suggested that EOL treatment for 24 days can decease the TNF- $\alpha, \mathrm{IL}-1 \beta,-6,-8$, and $-17 \mathrm{~A}$ in serum of CIA rats, whereas the IL-10 was significantly increased, suggesting that EOL may play a potential anti-RA therapeutic role by regulating these cytokines.

\section{CONCLUSION}

The results show that EOL exerts antiinflammatory activity and has a good therapeutic effect in CIA rats. The mechanism of action involves the inhibition of release of inflammatory cytokines. EOL also ameliorates symptoms of rheumatoid arthritis in CIA rats by inhibiting inflammatory reactions, thus suggesting it can be further developed as an anti-RA drug for use in humans.

\section{DECLARATIONS}

\section{Conflict of interest}

No conflict of interest is associated with this work.

\section{Contribution of authors}

We declare that this work was done by the author (s) named in this article and all liabilities pertaining to claims relating to the content of this article will be borne by the authors. In addition, all authors read and approved the manuscript for publication. 


\section{Open Access}

This is an Open Access article that uses a funding model which does not charge readers or their institutions for access and distributed under the terms of the Creative Commons Attribution License (http://creativecommons.org/licenses/by/ 4.0) and the Budapest Open Access Initiative (http://www.budapestopenaccessinitiative.org/rea d), which permit unrestricted use, distribution, and reproduction in any medium, provided the original work is properly credited.

\section{REFERENCES}

1. Smolen JS, Aletaha D, Mclnnes IB. Rheumatoid arthritis. Lancet 2016; 388: 2023-2038.

2. Chinese Rheumatology Association. 2018 Chinese guideline for the diagnosis and treatment of rheumatoid arthritis. Chin J Intern Med 2018; 57: 242-251.

3. Zhang $Q$, Peng $W$, Wei SJ, Wei DN, Li RL, Liu J, Peng LY, Yang S, Gao YX, Wu CJ, Pu XF. Guizhi-ShaoyaoZhimu decoction possesses anti-arthritic effects on type II collagen-induced arthritis in rats via suppression of inflammatory reactions, inhibition of invasion \& migration and induction of apoptosis in synovial fibroblasts. Biomed. Pharmacother. 2019; 118, 109367.

4. Guo Q, Wang YX, Xu D, Nossent J, Pavlos NJ, Xu JK. Rheumatoid arthritis: pathological mechanisms and modern pharmacologic therapies. Bone Res 2018; 6: 15

5. Emery P, Sebba A, Huizinga TWJ. Biologic and oral disease-modifying antirheumatic drug monotherapy in rheumatoid arthritis. Ann Rheum Dis 2013; 72: 18971904.

6. Wu JG, Peng $W, Y i J, W u$ YB, Chen TQ, Wong $\mathrm{KH}, W u$ JZ. Chemical composition, antimicrobial activity against Staphylococcus aureus and a pro-apoptotic effect in SGC-7901 of the essential oil from Toona sinensis (A. Juss.) Roem. leaves. J Ethnopharmacol 2014; 154: 198205.

7. Ji H, Kim H, Beuchat LR, Ryu JH. Synergistic antimicrobial activities of essential oil vapours against Penicillium corylophilum on a laboratory medium and beef jerky. Int J Food Microbiol 2018; 291: 104-110.

8. Liu TT, Yang TS. Antimicrobial impact of the components of essential oil of Litsea cubeba from Taiwan and antimicrobial activity of the oil in food systems. Int $\mathrm{J}$ Food Microbiol 2012; 156: 68-75.
9. Feng $T, X u Y$, Cai $X H, D u Z Z$, Luo XD. Antimicrobially active isoquinoline alkaloids from Litsea cubeba. Planta Med 2009; 75: 76-79.

10. Lin $B$, Zhang $H$, Zhao $X X$, Rahman $K$, Wang $Y, M a X Q$, Zheng CJ, Zhang QY, Han T, Qin LP. Inhibitory effects of the root extract of Litsea cubeba (lour.) pers. on adjuvant arthritis in rats. J Ethnopharmacol 2013; 147: 327-334.

11. CPCSEA guidelines for laboratory animal facility. Indian J Pharmacol 2003; 35: 257-274.

12. Zhou $X$, Mo BB. The study on chemical components of volatile oil which from Litsea cubeba (Lour.) Pers. Growing in Guizhou. J Guizhou Univ (Nat Sci) 2001; 18: 45-47.

13. Chen YF, Huang $Y$, Tang WZ, Qin LP, Zheng HC. Antinociceptive activity of paederosidic acid methyl ester (PAME) from n-butanol paederia of Paederia scandens in mice. Pharmacol Biochem Be 2009; 93: 97-104.

14. Li Q, Yang S, Yang S, Xin F, Wang M. Anti-inflammatory activity of phlomisoside $F$ isolated from Phlomis younghusbandii Mukerjee. Int Immunopharmacol 2015; 28: 724-730.

15. Peng W, Wang $L$, Qiu XH, Jiang YP, Han $T$, Pan $L$, Jia $X G$, Qin LP, Zheng CJ. Therapeutic effects of Caragana pruinosa Kom. roots extract on type II collagen-induced arthritis in rats. J Ethnopharmacol 2016, 191: 1-8.

16. Han X, Parker TL. Anti-inflammatory activity of clove (Eugenia caryophyllata) essential oil in human dermal fibroblasts. Pharm Biol 2017; 55: 1619-1622.

17. Chen LL, Zhang HJ, Chao J, Liu JF. Essential oil of Artemisia argyi suppresses inflammatory responses by inhibiting JAKSSTATs activation. I Ethnopharmacol 2017; 204: 107-117.

18. Ortiz MI, González-García MP, Ponce-Monter HA, Castañeda-Hernández G, Aguilar-Robles P. Synergistic effect of the interaction between naproxen and citral on inflammation in rats. Phytomed 2010; 18: 74-79.

19. Zavvar M, Abdolmaleki M, Farajifard H, Noorbakhsh F, Azadmanesh K, Vojgani M, Nikcnam MH. Collagen IIprimed Foxp3 transduced $T$ cells ameliorate collageninduced arthritis in rats: the effect of antigenic priming on $T$ regulatory cell function. Iran J Allergy Asthma Immunol 2018; 17: 361-371.

20. Liu D, Li T, Luo H, Zuo X, Liu S, Wu S. The effect of the cholinergic anti-inflammatory pathway on collageninduced arthritis involves the modulation of dendritic cell differentiation. Arthritis Res Ther 2018; 20: 263. 